\title{
Profile of Beneficiaries Rural Women under KVK in Madhya Pradesh
}

\author{
Deepika Thakur ${ }^{1}$, K. N. Pathak ${ }^{1}$, Minakshi Meshram ${ }^{2 *}$ and Vidhi Motiwale ${ }^{1}$ \\ ${ }^{1}$ Department of Extension Education RAK College of Agriculture, Sehore, RVSKVV Gwalior, \\ ${ }^{3}$ Extension Education, JNKVV, Jabalpur M.P, India \\ *Corresponding author
}

\section{A B S T R A C T}

\begin{tabular}{|l|}
\hline Ke y w or d s \\
$\begin{array}{l}\text { Socio - economic } \\
\text { profile, Rural } \\
\text { women, Krishi } \\
\text { vigyan kendra and } \\
\text { training }\end{array}$ \\
\hline Article Info \\
$\begin{array}{l}\text { Accepted: } \\
\text { 26 September } 2020 \\
\text { Available Online: } \\
\text { 10 October } 2020\end{array}$ \\
\hline
\end{tabular}

\section{Introduction}

India faces the most challenging task of transferring the fast emerging agricultural technologies to sustain the increase in farm productivity and economic viability of farming. A variety of extension programmes are implemented for creating awareness, educating and motivating the farmers, farmwomen and rural youth to adopt and manage the new agricultural technology in the fields/homes. This is one of the major contributing factors for making India a food surplus country. Agriculture plays a vital role in Indian economy and contributes 17 per cent to the total GDP and also provides employment to more than 60 per cent of the population. It seems that Indian economy is mostly rural and agricultural - based and dependent on Indian cultivable land consisting of mainly small holdings $(65 \%)$ and overall 86.2 per cent farmers are small and marginal (Meshram et al., 2019).

Madhya Pradesh is the second largest state with respect to area (30.82 $\mathrm{M}$ ha) and fifth in terms of population (72 Million) in the country. More than $70 \%$ of the area is rainfed dominated by small and marginal holdings. The socio-economic scenario in the state is observed by a lot of regional disparities 
especially among the tribal farmers consists of 52 districts and 11 diversified agro climatic zones. (Meshram et al., 2020)

Training is one of the important aspects of human resource development. Training is a mean to reduce the obsolescence among people and organization in the face of relent less technological innovation. Training plays a vital role in making the farmers more receptive and equipping them with new technologies. Training is the function of helping farmers in order to increase productivities. Vocational training is the important tool to prepare trainees for job that are based on manual or practical activities traditionally non-academic and totally related to a specific trade, occupation or vocation. There is a large section of Women farming community which is still unaware of technological developments in the field of Agriculture, Horticulture and Animal Husbandry.

For this purpose a number of extension programmes have been introduced by ICAR and state departments to reduce this gap and these programmes have yielded good results. Krishi Vigyan Kendra designs different kinds of training courses for the farmers/farm women.

Courses are based on the information received through family and village survey. No specific qualification is required to be the participant of the training programmes. No certificate is awarded after training programmes. After conducting the training programmes follow-up programmes are organized for converting the obtained skills of the trainees into practice. While designing the training programmes, the concept of farming system is taken into account to make the enterprises commercially viable.

The training starts from farm women production units such as fields, dairy units, poultry units, mushroom unit, beekeeping unit, sericulture unit, nursery raising etc. and closes with discussion.

The vocational training programmes take into account all methods and means which will result in skill development in rural women in the areas of their interest. Keeping in mind the impact of vocational training programmes are imparted by the KVK.

The main objective of the present paper is to Socio - personal and economic profile of trainee's rural women in Madhya Pradesh by vocational training programme conducted by Krishi Vigyan Kendra.

\section{Materials and Methods}

The study was carried out in Khargone district of Madhya Pradesh during 2015-16. Khargone is located towards West of Madhya Pradesh, lying wholly on the Narmada Valley. The total geographical area of the district covers 8153 square kilometers and consists of 9 development blocks. The Khargone block was selected purposively due to higher number of vocational training work organized by $\mathrm{KVK}$ in this block. The Khargone block is constituted of 128 villages, Out of them 12 villages were selected for vocational training purpose by KVK, for the present study. And each village 10 rural women were selected for trained by the KVK. Thus, a total of 120 women participants were taken for this study to study the Socio- economic profile of trainee's rural women by KVK in Madhya Pradesh.

The selected practicing farmers have been interviewed personally with the help of a well structured and pre-tested interview schedule to get the appropriate information. Frequency, percentage, mean and standard deviation were used for analyzing and interpreting the data. 
Age

The data presented in table 1 showed that majority of the rural women 46.70 per cent were of middle age group followed by old age group 30.00 per cent and young age group 23.30 per cent respectively. Thus, it can be concluded that in study area, most of the rural women were in middle age group followed by old and young. This finding is in conformity with the findings as reported by Nimoda (2013) and Chouhan (2015).

\section{Education}

The data presented in table 2 showed that, majority of the rural women 44.16 per cent were of primary and medium education group followed by illiterate and formal education group 31.66 per cent and higher education group 24.18 per cent respectively. Thus, it can be concluded that in study area, most of the rural women were found to medium education group followed by illiterate and formal education and higher education group. This finding is in conformity with the findings as reported by Deharia (2009) and Nimoda (2013).

\section{Caste status}

The data presented in table 3 showed that majority of the rural women 43.85 per cent found to other backward caste followed by general caste 35.80 per cent and SC/ST 18.40 per cent respectively. Thus, it can be concluded that in study area, most of the rural women were found to other backward caste group followed by general and SC/ST caste.

\section{Marital Status}

The table 4 revealed that maximum distribution of rural women was found in unmarried category $(56.70 \%)$ followed by married $(43.30 \%)$ respectively. Thus, it can be concluded that the majority of the rural women were unmarried.

\section{Size of family}

A look into table 5 shows that maximum of the rural women 45.00 per cent were found to have medium size of family followed by 33.30 per cent and 21.70 per cent rural women belongs to small and large size of family categories respectively. Thus, it can be concluded on the basis of above data that overall majority of the rural women having medium size of family followed by small and large size of family. This finding is in conformity with the findings as reported by Choudhary et al., (2011) and Dhanotiya (2012).

\section{Economic motivation}

The result presented in table 6 showed that out of the total rural women, the higher proportion of the rural women 35.83 per cent were of medium economic motivation group followed by high economic motivation group 33.34 per cent and low economic motivation group 30.83 per cent respectively. This is concluded that the study leads to the understanding that the phenomena with regards to the rural women community would be related more by the medium economic motivation group followed by high and low economic motivation group. This finding is in conformity with the findings as reported by Sharma (2008) and Yadav (2010).

\section{Training experience}

The data presented in table 7 showed that majority of the rural women 40.00 per cent found to low training experience group followed by medium training experience group 39.20 per cent and high training experience group 20.80 per cent respectively. Thus, it can be concluded that in study area, most of the rural women were found to low duration of training perceived group followed by medium and high duration of training perceived group. 
Table.1 Distribution of the rural women according to their age

\begin{tabular}{|r|c|c|c|}
\hline Variable & Categories & Frequency & Percentage \\
\hline \multirow{2}{*}{ Age } & Young & 28 & $\mathbf{2 3 . 3 0}$ \\
\cline { 2 - 3 } & Middle & 56 & $\mathbf{4 6 . 7 0}$ \\
\hline & Old & 36 & $\mathbf{3 0 . 0 0}$ \\
\hline & Total & $\mathbf{1 2 0}$ & $\mathbf{1 0 0 . 0 0}$ \\
\hline
\end{tabular}

Table.2 Distribution of the rural women according to their education

\begin{tabular}{|c|c|c|c|}
\hline Variable & Categories & Frequency & Percentage \\
\hline \multirow{2}{*}{ Education } & Illiterate and formal education & 38 & $\mathbf{3 1 . 6 6}$ \\
\cline { 2 - 4 } & Primary and middle education & 53 & $\mathbf{4 4 . 1 6}$ \\
\cline { 2 - 4 } & Higher education & 29 & $\mathbf{2 4 . 1 8}$ \\
\cline { 2 - 4 } & Total & $\mathbf{1 2 0}$ & $\mathbf{1 0 0 . 0 0}$ \\
\hline
\end{tabular}

Table.3 Distribution of the rural women according to their caste

\begin{tabular}{|c|c|c|c|}
\hline Variable & Categories & Frequency & Percentage \\
\hline \multirow{2}{*}{ Caste } & SC/ST & 22 & $\mathbf{1 8 . 4 0}$ \\
\cline { 2 - 4 } & O.B.C. & 55 & $\mathbf{4 5 . 8 0}$ \\
\cline { 2 - 4 } & General & 43 & $\mathbf{3 5 . 8 0}$ \\
\cline { 2 - 4 } & Total & $\mathbf{1 2 0}$ & $\mathbf{1 0 0 . 0 0}$ \\
\hline
\end{tabular}

Table.4 Distribution of the rural women according to marital status

\begin{tabular}{|c|c|c|c|}
\hline Variable & Categories & Frequency & Percentage \\
\hline Marital status & Unmarried & 68 & $\mathbf{5 6 . 7 0}$ \\
\cline { 2 - 4 } & Married & 52 & $\mathbf{4 3 . 3 0}$ \\
\hline & Total & $\mathbf{1 2 0}$ & $\mathbf{1 0 0 . 0 0}$ \\
\hline
\end{tabular}

Table.5 Distribution of the rural women according to their family size

\begin{tabular}{|c|c|c|c|}
\hline Variable & Categories & Frequency & Percentage \\
\hline \multirow{2}{*}{ Family size } & Small & 40 & $\mathbf{3 3 . 3 0}$ \\
\cline { 2 - 4 } & Medium & 54 & $\mathbf{4 5 . 0 0}$ \\
\cline { 2 - 4 } & Large & 26 & $\mathbf{2 1 . 7 0}$ \\
\cline { 2 - 4 } & Total & $\mathbf{1 2 0}$ & $\mathbf{1 0 0 . 0 0}$ \\
\hline
\end{tabular}


Table.6 Distribution of the rural women according to their economic motivation

\begin{tabular}{|c|c|c|c|}
\hline Variable & Categories & Frequency & Percentage \\
\hline Economic motivation & Low & 37 & $\mathbf{3 0 . 8 3}$ \\
\cline { 2 - 4 } & Medium & 43 & $\mathbf{3 5 . 8 3}$ \\
\cline { 2 - 4 } & High & 40 & $\mathbf{3 3 . 3 4}$ \\
\hline & Total & $\mathbf{1 2 0}$ & $\mathbf{1 0 0 . 0 0}$ \\
\hline
\end{tabular}

Table.7 Distribution of the rural women according to their training experience

\begin{tabular}{|c|c|c|c|}
\hline Variable & Categories & Frequency & Percentage \\
\hline Training experience & Low & 48 & $\mathbf{4 0 . 0 0}$ \\
\cline { 2 - 4 } & Medium & 47 & $\mathbf{3 9 . 2 0}$ \\
\cline { 2 - 4 } & High & 25 & $\mathbf{2 0 . 8 0}$ \\
\hline
\end{tabular}

Table.8 Distribution of the rural women according to their type of vocational training

\begin{tabular}{|c|c|c|c|}
\hline Variable & Categories & Frequency & Percentage \\
\hline Type of vocational & Short type & 48 & $\mathbf{4 0 . 0 0}$ \\
\hline \multirow{2}{*}{\begin{tabular}{c} 
training \\
\cline { 2 - 4 }
\end{tabular}} & Medium type & 48 & $\mathbf{4 0 . 0 0}$ \\
\cline { 2 - 4 } & Long type & 24 & $\mathbf{2 0 . 0 0}$ \\
\hline & Total & $\mathbf{1 2 0}$ & $\mathbf{1 0 0 . 0 0}$ \\
\hline
\end{tabular}

Table.9 Distribution of the rural women according to their information seeking behaviour

\begin{tabular}{|c|c|c|c|}
\hline Variable & Categories & Frequency & Percentage \\
\hline Information seeking behaviour & Low & 27 & $\mathbf{2 2 . 5 0}$ \\
\hline & Medium & 59 & $\mathbf{4 9 . 1 6}$ \\
\hline & High & 34 & $\mathbf{2 8 . 3 4}$ \\
\hline & Total & $\mathbf{1 2 0}$ & $\mathbf{1 0 0 . 0 0}$ \\
\hline
\end{tabular}

Table.10 Distribution of the rural women according to their social participation

\begin{tabular}{|c|c|c|c|}
\hline Variable & Categories & Frequency & Percentage \\
\hline Social participation & Low & 41 & $\mathbf{3 4 . 1 6}$ \\
\cline { 2 - 4 } & Medium & 50 & $\mathbf{4 1 . 6 6}$ \\
\cline { 2 - 4 } & High & 29 & $\mathbf{2 4 . 1 8}$ \\
\cline { 2 - 4 } & Total & $\mathbf{1 2 0}$ & $\mathbf{1 0 0 . 0 0}$ \\
\hline
\end{tabular}

Table.11 Distribution of the rural women according to their socio economic status

\begin{tabular}{|c|c|c|c|}
\hline Variable & Categories & Frequency & Percentage \\
\hline Socio economic status & Low & 28 & $\mathbf{2 3 . 3 3}$ \\
\cline { 2 - 3 } & Medium & 53 & $\mathbf{4 4 . 1 6}$ \\
\hline & High & 39 & $\mathbf{3 2 . 5 1}$ \\
\hline
\end{tabular}




\section{Type of vocational training}

The data presented in table 8 showed that majority of the rural women 40.00 per cent found to pertaining short and medium type of vocational training followed by long type of vocational training 20.00 per cent respectively. Thus, it can be concluded that in study area, most of the rural women were found to short and medium type of vocational training followed by and long type of vocational training. This finding is in conformity with the findings as reported by Sharma (2008) and Nimoda (2013).

\section{Information seeking behaviour}

The data presented in table 9 showed that majority of the rural women 49.16 per cent found to medium information seeking behaviour group followed by high information seeking behaviour group 28.34 per cent and low information seeking behaviour group 22.50 per cent respectively. Thus, it can be concluded that in study area, most of the rural women were found to medium information seeking behaviour group followed by high and low information seeking behaviour group. This finding is in conformity with the finding as reported by Sharma (2008), Dabar (2009) and Nimoda (2013).

\section{Social participation}

The data presented in table 10 showed that majority of the rural women 41.66 per cent found to medium social participation group followed by low social participation group 34.16 per cent and high social participation group 24.18 per cent respectively. Thus, it can be concluded that in study area, most of the rural women were found to medium social participation group followed by low and high social participation group. This finding is in conformity with the finding as reported by Dabar (2009).

\section{Socio economic status}

The data presented in table 11 showed that majority of the rural women 44.16 per cent have medium socio economic status followed by high socio economic status 32.51 per cent and low socio economic status group 23.33 per cent respectively. Thus, it can be concluded that in the study area, most of the rural women were have medium socio economic status followed by high and low. This finding is in conformity with the finding as reported by Dabar (2009) and Deharia (2009).

In conclusion the training plays a vital role in making the farmers more receptive and equipping them with new technologies. Training is the function of helping farmers in order to increase productivities.Vocational training is the important tool to prepare trainees for job that are based on manual or practical activities traditionally non-academic and totally related to a specific trade, occupation or vocation. The findings of the study revealed that majority of the trainees rural women were middle-aged, having medium school education, belonged to other backward caste, most of women were unmarried, medium family size, medium economic motivation, having low duration of training perceived, having short type of vocational training, medium information seeking behaviour, medium social participation and medium socio economic status.

\section{References}

Choudhary, Keerti; Khare,N.K. and Pande,A.K. 2011. Impact of vocational training programme conducted by Krishi Vigyan Kendra on rural women for income and employment generation. ABSTRACTS National Seminar Held on September 27-29 at J.N.K.V.V. 
Jabalpur.

Chouhan, Roshani. 2015. A study on level of perfection of farm women in Agricultural activities through Madhya Pradesh Women in Agriculture Project (MAPWA) in Jhabua district. M.Sc. (Ag.) Thesis Submitted to Rajmata Vijayaraje Scindia Krishi Vishwa Vidyalaya, Gwalior.

Dabar Sheela, 2009. A study on training needs of farm women on wheat production technology in Hoshangabad district of Madhya Pradesh. M.Sc (Agi) Thesis submitted to College of Agriculture Indore.

Deharia, Anita. 2009. Impact of Krishi Vigyan Kendra in changing the knowledge and socio-economic status of the tribal women in Chhindwara district of Madhya Pradesh. M.Sc. (Ag.) Thesis Submitted to Jawaharlal Nehru Krishi Vishwa Vidyalaya, Jabalpur.

Dhanotiya, Barkha. 2012. Study on women entrepreneurial behaviour in self help group through KVK Kasturba Gram Indore district of M.P. M.Sc. (Ag.) Thesis Submitted to Rajmata Vijayaraje Scindia Krishi Vishwa Vidyalaya, Gwalior.

Meshram M, Khare NK and Singh SRK. 2019. Assessing Integrated Farming System Models Apropos Employment
Generation Potential in Madhya Pradesh. Indian Journal of Extension Education, 55 (3): 65-68.

Meshram M, Khare NK and Singh SRK. 2020. Socio-economic profile of integrated farming system practicing farmers in Madhya Pradesh state, The Pharma Innovation Journal, SP-9(4): 155-159.

Nimoda Usha. 2013. A study on information and training needs of farm women on crop production technology in Sehore district of Madhya Pradesh. M.Sc. (Ag.) Thesis Submitted to Rajmata Vijayaraje Scindia Krishi Vishwa Vidyalaya, Gwalior.

Sharma, Abhilasha. 2008. A study on the role of farm women in agriculture operations \& decision making pattern in Sanchi block of Raisen district of Madhya Pradesh. M.Sc. (Ag.) Thesis Submitted to Jawaharlal Nehru Krishi Vishwa Vidyalaya, Jabalpur.

Yadav, Reena. 2010. A study on women's participation and decision making pattern in agricultural activities in Sehore district of Madhya Pradesh. M.Sc. (Ag.) Thesis Submitted to Rajmata Vijayaraje Scindia Krishi Vishwa Vidyalaya, Gwalior.

\section{How to cite this article:}

Deepika Thakur, K. N. Pathak, Minakshi Meshram and Vidhi Motiwale 2020. Profile of Beneficiaries Rural Women under KVK in Madhya Pradesh. Int.J.Curr.Microbiol.App.Sci. 9(10): 3535-3541. doi: https://doi.org/10.20546/ijcmas.2020.910.407 